\title{
A Descriptive Study on Students' Perceptions About The Foreign Volunteer's Roles in Learning Process of The Seventh Grade at Smpn 2 Glagah Banyuwangi in 2015/2016 Academic Year
}

\author{
RIZKI AMALIA \\ English Education Department, PGRI University of Banyuwangi
}

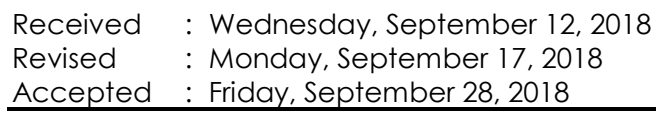

\section{Abstract}

Perception is the experience about objects, events, or the relations that are gotten by concluding the information and interpreting the mesagge. The more complex definition is given by Pareek in Alex (2003:446) who states that perception is a process of receiving, selecting, organizing, interpreting, evaluating, and giving relation to stimulate of the sense. Based on the definition above, it can be summarized that perception is a process of recognizing/receiving the stimuli in form of events, objects, or others through the sense, then those stimuli are organized and interpreted, and lastly giving reaction toward them.

To achieve the research purposes, this research uses analytic induction. The researcher use theory from Walters that is self perception Self perception is based on self-efficicacy. It means that the perception occurs based on individual mind (intrinsic). Because the student's appreciate about the foreign volunteer's role by themselves. They will appreciate does the foreign volunteers give positive or negative impact.Learning with foreign volunteer made the seventh grade's at SMPN 2 GlagahBanyuwangi more interested to study English and foreign volunteer give big impact to the students, so they can study hard.

Based on the result, it is suggested To the teacher it is suggested to imitate the techniques applied by foreign volunteer, or the teacher can consolidate the teacher's techniques and the foreign volunteer's techniques. Students should be active, creative and also fun in teaching learning process and be more confident and do not afraid with English lesson. Students should pay attention to teacher explanation. While for the the other researcher, it is suggested to use the information to know the student's perceptions about the foreign volunteer's roles in English learning process at SMPN 2 Glagah. The other researcher are also suggested to use it as reference if having similar research

Keywords:Perception, foreign volunteer

\section{A. Introduction}

The way English is taught plays a crucial role in its position, status and success as a foreign language in Indonesia (Lie, 2007). Students generally only encounter small amounts of English inside and outside classrooms due to English not being used for language instruction in 
classrooms, nor as a tool of communication during social interaction. This absence places a large responsibility on English teachers to ensure students learn English in a supportive atmosphere, and bring successful language learning into the classroom. Thus, teachers' language knowledge and teaching skills, together with a suite of other complex skills, are important in the teaching of EFL (Bartels, 2009).

In Indonesia, English is a foreign language. It means the students must learn English when they want to be a master in English. It should make them become master in four skills in English, such as listening, speaking, reading and writing.

Nowadays,some of junior and senior high schools are helped by the foreign volunteers in teaching English. The coming of foreign volunteers to Indonesia from year to year never stopped

According to Mahartana (2008), many reasons that make foreign volunteerhappy to choose volunteer activities in Indonesia,such as (1) learning about a new culture and country, (2) gaining leadership skills, (3) skills to benefit other people, (4) seeing a new culture from the inside and not as tourist, (5) learning new life skills, (6) developing new experience, (7) can master the Indonesian language.

Based on the opinion, the researcher is eager to do a research entitled "A Descriptive Study of the Students' Perceptions about the Foreign Volunteer's Roles in English Learning Process of the Seventh Grade at SMPN 2 Glagah Banyuwangi in 2015/2016 Academic Year

\section{Problem of the Research}

The problem of this research is formulated in the following question : How are students' perceptions about the foreign volunteer's roles in English learning process of the seventh grade at SMPN 2 Glagah Banyuwangi in 2015/2016 Academic Year?

\section{Objective of the Research}

Related to the research and research problem, the objective of this research isto analyze the students' perceptions about the foreign volunteer's roles in English learning process of the seventh grade at SMPN 2 Glagah Banyuwangi in 2015/2016 Academic Year

\section{Significance of the Research}

This result of this study is expected to give a specific information about the students' perception on the roles of foreign volunteer in English learning process of the seventh grade at SMPN 2 Glagah Banyuwangi in 2015/2016 Academic Year.

\section{Operational Definition of the Key Terms}

a. Foreign Volunteers :

Foreign volunteer are those give time, effort and talent to a need or cause without profiting monetarily

b. Student's Perceptions :

Student's perceptions are ability of the students in seeing or understanding something. 
c. Roles:

An attitude or behavior which is expected by many people or a group of people against a person who has certain positionor status.

d. English Learning Process :

The process of interaction between students and teacher in English learning activities.

\section{Scope and limitation of the Study}

This study would like to describe the students' perception about the foreign volunteer's roles in English learning process. The researcher just focused to describe the students' perception about motivation learning, and interesting learning.

\section{B. Volunteering}

According to Merril(2006:10), definition of volunteering and the use of the term volunteer vary within and between countries and settings. Volunteering, at different times and In different places, is used to (a) define the setting of work, such as formal or informal; (b) define the value of work; and/or (c) define the scope of work, such as reaching out beyond the confines of employment and normal responsibilities or performing activities that benefit others. Safrit and Merrill (1995) identified the four defining tenants of volunteering:

- Volunteerism implies active involvement. The act of volunteering involves active participation or contributions of time, energies or talents; it is never seen as the giving of financial or material resources as a donor/sponsor.

- Volunteering is uncoerced. Individuals givetheir time, energies and talents freely and for whatever motivation(s).

- Volunteering is not (primarily) motivated by financial gain. Many programs reimburse volunteers for personal and material expenses incurred during their service. These financial remunerations have been termed reimbursement, stipend or living expenses, but never salary

- Volunteering focuses on the common good. Although reasons for volunteering may be individualized and perhaps even selfserving, the outcomes of volunteering are focused beyond the individual towards a larger, common good.

\section{Perception}

Rakhmat in Alex (2003:446) stated that perception is the experience about objects, events, or the relations that are gotten by concluding the information and interpreting the mesagge. The more complex definition is given by Pareek in Alex (2003:446) who states that perception is a process of receiving, selecting, organizing, interpreting, evaluating, and giving relation to stimulate of the sense. Based on the definition above, it can be summarized that perception is a process of recognizing/receiving the stimuli in form of events, objects, or others through the sense, then those stimuli are organized and interpreted, and lastly giving reaction toward them. 
Based on that explanation, it can be stated that there are five types of perception. They are self perception, learned perception, physical perception, and cultural perception. Those types are classified based on the source of the perception coming. In other words, the types of perception can be seen from where the stimulus comes in order tobuild the perception itself.

\section{English Learning Process}

Learning is a change in a person's ability to behave in certain ways. This change can be traced to two key factors past experience with the subject (e.g., in the field) and practice (e.g., training in the classroom). Learning can occur both formally (inside the classroom) and informally (around the dinner table) (Connick, 1997). Formal learning does not occur by accident.It is the direct result of a program designed by an instructor (Butler \& McManus, 1998). An adult learner may intentionally set out to learn by taking classes or by reading about a subject. She/he may also gather information through the experience of living that changes the learner's behavior. Informal learning occurs spontaneously and continually changes the adult learner's behavior. Ideally, learning is created through the blending of individual curiosity, reflection, and adaptation (Stewart, 2003). English learning process is the process to gain knowledge or skill in English subject.

\section{E. Roles of Teacher}

According to Zeiger (2000:1), a teacher's role involves more than simply standing in front of a classroom and lecturing. In fact, though even a teacher spends the majority of the day in the classroom, the actual teaching component is only part of the job. An effective teacher understands that teaching involves wearing multiple hats to ensure that the school day runs smoothly and all students receive a quality education.

\section{F. The Research Methodology}

The design of this research is qualitative research. According to Moriarty (2011:2), qualitative method is a broad term that can be applied to a range of research approaches that have their theoretical origins in a range of disciplines including anthropology, sociology, philosophy, social psychology and linguistic. The data in this study are presented descriptively in order to give clear explanation on students' perceptions about the foreign volunteer's roles in English learning process of the seventh grade at SMPN 2 Glagah Banyuwangi in 2015/2016 Academic Year

\section{Area Determination Method}

Purposive method is used to determine the research area. In this qualitative research, SMPN 2 Glagah is chosen as the research location because the researcher found foreign volunteer there.

\section{Data Resources}

a. Respondent

Respondent is the person who gives the "response" or responses to what is required or determined by the investigators. While on qualitative research, respondent position is very 
important. On this occasion the respondentsare the seventh grade at SMPN 2 Glagah Banyuwangi in 2015/2016

Academic Year. The seventh grade at SMPN 2 Glagah Banyuwangi consists of six classses. Every class consistsof 35-40 students. The researcher took three of thesix classes using purposive sampling because there are just three classes taught by the foreign volunteer. They arethe seventh grade is of $A, B$, and $C$ classes. Therefore, the whole respondents are109 students.

b. Informants

Informant in the research is a person who provides privileged information about a person. The Informants are English teacher, foreign volunteer, and administration staff

\section{Method of Data Collecting}

To analyze the data, the researcher applied Questionnaires. Questionnaire are very convenient way of collecting useful comparable data from a large number of individuals. However qestionnaires can only produce valid and meaningful results if the questions are clear and precise and if they are asked consistenly across all respondents. Careful consideration therefore needs to design of qestionnaires (Marther, et al,2009:9).

Dealing with data collection methods, this research applied the Questionnaire. The questionnaire is number of list written question submitted to respondent to acquire the information of what they undergo in the instructional process and in the learning activity, so the method is utilized or implemented to theacquired data about the students' perceptions about the foreign volunteer's roles in English learning process of the seventh grade at SMPN 2 Glagah Banyuwangi in 2015/2016 Academic Year. The questionaires contain ten questions, written in the form of multiple choice and consist of only two items. The gratings of questionnaire in this research involve students' motivation in learning, and interest of learning while learning English with the foreign volunteer.

\section{Method of Data Analysis}

To analyze the data, the researcher applied analytic induction. According to Smelser (2001), analytic induction is a research logic used to collect data, develop analysis, and organize the presentation of research findings. To achieve the purpose of the research, the researcher use analytic induction. There were some procedures in analytic induction. First the researcher collected the data about perceptions of the students about the foreign volunteer. Then classified the data into agree and disagree. The third step is identifying the data. The analysis process continued by relating the result of the questionnaires with the theory. The last step is conclusion drawing. 


\section{G. Result and Discussion}

\section{Result of the Questionnaire}

Based on the questionnaires that were given, the researcher knows that almost all of the seventh $A, B$ and $C$ class students of SMPN 2 GlagahBanyuwangi agree with the statement in the questionnaire. It means that students have a good or positive perceptions about the foreign volunteer. The data of student's perceptions can be presented completely as follows :

a. The statement is "Cara mengajar yang diberikan relawan asing lebih menyenangkan daripada guru sebelumnya."There are 81 (74.3\%) students agree and 28 (25.7\%) students disagree with the first statement. It means most of the students feel happier when they are taught by foreign volunteer than the English teacher.

b. The statement is "Siswa lebih memahami pelajaran bahasa Inggris bersama relawan asing."In the second statement, the researcher count that there are $72(66 \%)$ students agree with the statement and37 (34\%) students disagree with the statement. It shows that most of the students can understand the subject which is taught by foreign volunteer.

c. The statement is "Kedatangan relawan asing membuat siswa lebih menyukai pelajaran bahasa Inggris."From one hundred and nine students, there are 91 (83.5\%) students agree with the statement and the 18 (16.5\%) disagree with the statement. The result shows that arrival of foreign volunteer gives big effect to students in learning English. It is proved by almost all of the students like the English lesson.

d. The statement is "Penjelasan relawan asing lebih jelas dibandingkan dengan gurubahasalnggris." There are 98 (89.9\%) students agree with the statement and 11 (10.1\%) disagree with the statement. It means the foreign volunteer's explanation is clearly. It is showed by most of the students agree with the fourth statement.

e. The statement is "Dengan bahasa yang tidak terlalu fasih,tidakmempengaruhi siswa dalam proses belajar bahasa Inggris bersama relawan asing." There are 73 (66.9\%) students agree with fifth statement while 36 (33.1\%) students do not agree with the statement. It means foreign volunteer's language does not give big impact In teaching learning process. Students still understand about what the foreign volunteer's means.

f. The statement is "Relawan asing menggunakan media pembelajaran saat pelajaran bahasa Inggris." In the sixth statement, the researcher counts that there are 92 (84.4\%) students agree with the statement and 17 (15.6\%) students disagree with the statement. It can be conclude that the foreign volunteer use media in teaching English. 
9. The statement is "Adanya relawan asing mendorong motivasi siswa untuk lebih giat belajar Bahasa Inggris." 77 ( 70.6\%) students agree with the seventh statement while 32 (29.4\%) students do not agree with the statement. It means foreign volunteer give impact to the students so they can study hard.

h. The statement is "Relawan asing membantu siswa yang kesulitan dalam mengerjakan latihan." There are 85 (77.9\%) students agree with the statement and 24 (22.1\%) disagree with the statement. It means that the foreign volunteer always help the students who have difficulty in learning English. It is proved by almost all of the students agree with the statement.

i. The statement is "Dalam menjelaskan materi relawan asing menguasai materi dengan baik tidak hanya mengandalkan buku pegangan." From one hundred and nine students, there are $94(86.2 \%)$ students agree with the statement while 15 (13.8\%) students disagree with the statement. It means foreign volunteer has mastered the material because she does not need handout or English book in teaching English.

j. The statement is "Relawan asing bisa menciptakan suasana belajar yang menyenangkan." In the last statement, the researcher counts that there are $85(77.9 \%)$ students agree with the statement and $24(22.1 \%)$ students disagree with the statement. It means the students enjoy the class because the foreign volunteer can create the situation of the class became enjoyable and comfortable.

\section{General Description of the Research Area}

SMP Negeri 2 Glagah is located on Jln. Kenjo No. 45 Glagah Banyuwangi. Dra. Enny Purnamaningrum, M.Pd is the headmaster of SMP Negeri 2 Glagah. The following is the profile of SMP Negeri 2 Glagah :

School Name : SMP NEGERI 2 GLAGAH

Address : Jln. Kenjo No. 45 Glagah Banyuwangi

No. Telp. / Fax : (0333) 418566

NPSN : 20525649

Status : Negeri

\section{Data Presentation}

To obtain the required data, the researcher has conducted the research using questionnaire. The questionnaire was given on June, 1st 2016. The following is the result of the questionnaire

\section{Discussion}

This section presents the discussion of the findings of the research. It concerned about students' perceptionson the foreign volunteer's roles in English learning process of the seventh grade at SMPN 2 Glagah Banyuwangi.

Based on the result of the research the students are more interested in learning English with foreign volunteer because foreign volunteer gives motivation and positive impact for the students. Foreign volunteer here is the same with native speaker of 
English because her mother tongue is English. It relates to Dr. İsmet ŞAHIN's statement that the study investigated the effect of native speaker teachers of English on the attitudesand success of EFL learners in Turkish setting. The results confirm that the learners who are exposed to native speaker teachers of English have more positive attitudes towards target language community and are more successful in English lessons compared to those who are not exposed to any native speaker teachers of English (2005:29).

According to Dr. İsmet ŞAHIN (2005:30), teaching English to speakers of other languages has gained importance very rapidly in recent years. One of the vital variables in the learning situation is the teacher himself. His skill and his personality are instrumental in creating the conditions for learning. His skill is dependent on two factors, his own proficiency in the language and his knowledge of and expertise in methods and techniques of language teaching. It relates to the findings of the research that the ability of foreign volunteer in teaching English can influence the student's understanding. The foreign volunteer does not need a handout in teaching learning process, so the foreign volunteer can focus to the students.

Media is important thing in teaching English. It relates to the Bolla Mallikharjuna Rao that most of the students in the trial class improved in their comprehension skills as well as their vocabulary after reading newspapers, magazines, journals, articles and other printed materials provided by the teacher. Students enthusiastically responded to the transistor carried by the teacher and the occasional trips to the TV room (2014:141). Teaching English using media can also create the enjoyable classroom. It relates to Bolla Mallikharjuna Rao's statement that heartening to note that all of them irrespective of their mediumof instruction showed tremendous interest in listening and watching programme. It was also noticed that there was a deep sense of joy and fulfillment among the students because they got an opportunity to enjoy learning English language without being conscious of grammar rules. All of them enjoyed themselves while learning from these sources and quite happily narrated how they used media in order to learn English (2014:141).

Based on fact, it can be stated that there are many types of perception. In this research, the researcher use theory from Walters that is self perception Self perception is based on self-efficicacy. It means that the perception occurs based on individual mind (intrinsic). Because the student's appreciate about the foreign volunteer's role by themselves. They will appreciate does the foreign volunteers give positive or negative impact

\section{H. Conclusion}

The analysis in Chapter IV leads the researcher to draw the following conclusions: Learning with foreign volunteer made the seventh grade's at SMPN 2 Glagah Banyuwangi more interested to study English 
and foreign volunteer give big impact to the students, so they can study hard.

\section{Acknowledgement}

Alhamdulillahirobbil' Alamiin. In the name of Allah SWT, the beneficent and merciful. All praise is merely to The Mightiest Allah SWT, the lord of the worlds, for the gracious mercy and tremendous blessing that enable me to accomplish this thesis. My best gratitude to our prophet Muhammad Sallallahualaihiwasallam for His Syafa' at.

During writing this thesis, there are a lot of people who give great helps from the beginning phase of the research until it is finished. I would like to express my thanks to everyone who had contribute suggestions and critics.

The researcher greatly hopes that this thesis will be useful for the reader or everyone who read this thesis and thanks a lot forhelps. May Allah bless you all, Amen.

\section{J. References}

Administration methods. (2010) Retrieved March 2, 2012, from Student Voice Web site: https://www.studentvoice.com/app/w

Alex, Sobur. 2003. Psikologi Umum. Bandung: CV.Pustaka Setia

Bartels, N. (2009). Knowledge about language. In a Burns \& J.C.

Richards (Eds.) The Cambridge guide to language teacher education, pp. 125-134. New York, NY: Cambridge University Press.

Bimo, Walgiato.2014. Pengantar Psikologi Umum.Yogyakarta :Andi offset

Easwaramoorthy \& Zarinpoush (2006). Interviewing for research. Canada : Avenue University Bereau Toronto.

Jo Moriarty (2011) Qualitative Methods Overview.School for social care research.London :Hougtoon street.

Mahartana (2008).Volunteer in Balic Copyright to Yayasan Widya Sari. Indonesia :Bali http://www.volunteerinbali.org

Marry, F. (2006). The international journal of volunteer administration, p. 10. Columbus, Ohio, USA

Michael, R. (2000). Reseach design in Qualitative/Quantitative Method, pp. 148-149. University of Minnesota.

Nigel Mathers, Nick Fox, \& Amanda Hunn 2009 Surveys and questionnaires National Institute for Healt research. University Park Nottingham

StecyZeiger (2000) What is the Role of Teachers in Education? http://work.chron.com/role-teachers-education-8807.html 
http://www.qualityresearchinternational.com/socialresearch/a nalyticinduction. htm

Steward (2003) The learning process Published by Jones \& Barlett p.58

------ (2007). Oxford Student's Dictionary.New York : Oxford University Press.

------ (2008). Oxford Learner's Pocket Dictionary.New York : Oxford University Press. 